Jurnal Riset Agama

Volume 1, Nomor 3 (Desember 2021): 132-156

DOI: $10.15575 /$ jra.v1i3.15089

https://journal.uinsgd.ac.id/index.php/jra

\title{
Studi Perbandingan Fitur-Fitur Aplikasi Al-Quran Digital Karya \\ Greentech Apps Foundation dan Aplikasi Al-Quran Muslim Media untuk Mengetahui Perbedaan Kedua Fitur aplikasi
}

\author{
Ahmad Yani' ${ }^{1}$ Hepni Putra ${ }^{2}$, Andika ${ }^{3}$, Muria Khusnun Nisa ${ }^{4}$, Eka Mulyo \\ Yunus ${ }^{5}$ \\ 1,2Program Studi Ilmu Al-Quran dan Tafsir, Fakultas Ushuluddin, Adab \\ dan Dakwah, IAIN Pontianak, Indonesia \\ 3Program Studi Studi Agama-Agama, Fakultas Ushuluddin dan Studi \\ Agama, UIN Sulthan Thaha Saifuddin Jambi, Indonesia \\ 4Program Studi Studi Agama-Agama, Fakultas Ushuluddin, UIN Syarif \\ Hidayatullah Jakarta, Indonesia \\ 5Program Studi Al-Quran dan Tafsir, Fakultas Ushuluddin dan \\ Humaniora, UIN Walisongo, Indonesia \\ ahmadyani.official@gmail.com, hepniputra89@gmail.com, \\ andikaandikaa61@gmail.com, muria6@gmail.com, \\ ekayunus02@gmail.com
}

\begin{abstract}
Digitalization of the Koran is a process of changing the vehicle from the beginning of the Koran being limited to written printed form to digital, for example, the Koran (tafsir and pe word) by Greentech Apps Foundation and al-Quran interpretation and word by word by Muslim Media. Not many people know information about the background of the formation and differences related to the features of the two applications. The purpose of this research is to find out the background of the formation, features, advantages, and disadvantages, and to compare the features of the two applications. The method used in this article is descriptiveanalytical. The software that will be investigated in this research is the application of the Koran (tafsir and pe- word) by Greentech Apps Foundation and Al-Quran Muslim Media. Researchers assume that each application must have a significant comparison. This assumption is proven by examining the features of the two applications. This study concludes that the two applications can be compared in terms of features of interpretation, translation per word, audio, recitation, background display, dictionaries, prayers, and prayer schedules. Through this research, the researcher recommends programming experts and application developers so that in the future they can develop digital Al-Quran
\end{abstract}


Jurnal Riset Agama, Volume 1, Nomor 3 (Desember 2021): 132-156

Ahmad Yani, Hepni Putra, Andika, Muria Khusnun Nisa, Eka Mulyo Yunus/Studi Perbandingan Fitur-Fitur Aplikasi Al-Quran Digital Karya Greentech Apps Foundation dan Aplikasi Al-Quran Muslim Media untuk Mengetahui Perbedaan Kedua Fitur aplikasi

applications by prioritizing the advantages of comparing the two applications or even adding even better features to become a superior application in the future.

Keyword: Al-Qur'an; Application; Digitization.

\begin{abstract}
Abstrak
Digitalisasi al-Quran merupakan proses perubahan wahana dari yang awalnya al-Quran sebatas bentuk cetakan tertulis menjadi digital, contohnya yakni al-Quran (tafsir \& per kata) karya Greentech Apps Foundation dan al-Quran tafsir dan per kata karya Muslim Media. Tidak banyak yang mengetahui informasi mengenai latar belakang pembentukan serta perbedaan terkait fitur-fitur daripada kedua aplikasi tersebut. Tujuan daripada penelitian ini adalah untuk mengetahui latar belakang pembentukan, fitur-fitur, kelebihan dan kekurangan, serta untuk mengetahui perbandingan fitur-fitur kedua aplikasi tersebut. Metode yang digunakan dalam artikel ini adalah deskriptif-analitis. Adapun software yang hendak diteliti pada penelitian ini yakni aplikasi al-Quran (tafsir \& per kata) karya Greentech Apps Foundation dan al-Quran Muslim Media. Peneliti berasumsi bahwa setiap aplikasi pasti memiliki perbandingan yang signifikan. Asumsi tersebut terbukti dengan meneliti fitur-fitur kedua aplikasi tersebut. Penelitian ini menyimpulkan bahwa kedua aplikasi tersebut dapat dilihat perbandingannya dari segi fitur tafsir, terjemah per kata, audio, tajwid, tampilan background, kamus, doa, dan jadwal salat. Melalui penelitian ini, peneliti merekomendasikan kepada para ahli programming dan developer aplikasi agar kedepannya dapat mengembangkan aplikasi al-Quran digital dengan mengedepankan sisi kelebihan dari perbandingan kedua aplikasi tersebut atau bahkan menambahkan fitur-fitur yang lebih baik lagi agar menjadi sebuah aplikasi yang lebih unggul di masa mendatang.
\end{abstract}

Kata Kunci: Al-Quran; Aplikasi; Digitalisasi.

\title{
Pendahuluan
}

Bidang teknologi saat ini kian maju dan kemajuannya sangat mudah untuk dijumpai (Aksin, 2016). Pada masa sekarang, perkembangan teknologi membawa dampak yang sangat signifikan bagi manusia guna memenuhi kebutuhan hidup serta memudahkan segala proses. Proses tersebut mencakup proses transaksi ekonomi, komunikasi, informasi 
Jurnal Riset Agama, Volume 1, Nomor 3 (Desember 2021): 132-156

Ahmad Yani, Hepni Putra, Andika, Muria Khusnun Nisa, Eka Mulyo

Yunus/Studi Perbandingan Fitur-Fitur Aplikasi Al-Quran Digital Karya

Greentech Apps Foundation dan Aplikasi Al-Quran Muslim Media untuk

Mengetahui Perbedaan Kedua Fitur aplikasi

bahkan proses pencarian indeks kata yang ada pada al-Quran (Muzakky, 2020). Perkembangan peradaban manusia yang pesat, semakin menyebabkan majunya teknologi sebagai sarana yang mempermudah aktivitas manusia. Teknologi saat ini semakin dilirik. Adapun terkait alQuran, saat ini semakin muncul berbagai versi al-Quran digital. Ada yang berbasis software komputer, ponsel atau bahkan dalam bentuk website (Hidayat, 2016).

Penelitian terkait tafsir al-Quran di era digital harus lebih memasifkan kembali akan upaya menjaga keotentikan al-Quran. Digitalisasi merupakan salah satu upaya meningkatkan kualifikasi kajian serta hierarki keilmuan tafsir al-Quran yang sudah dirumuskan oleh para ulama terdahulu dalam rangka menjaga al-Quran agar tetap eksis dan hidup serta dapat diaktualisasikan dengan menyesuaikan perkembangan zaman tanpa merusak isi dari kandungannya (Mubarok \& Romdhoni, 2021).

Jika zaman dahulu al-Quran sebatas mushaf konvensional bertulisan tangan dan dicetak dengan berbagai bentuk serta variasi tulisan, namun saat ini seiring dengan perkembangan dan kemajuan teknologi, al-Quran mulai memasuki era digital. Al-Quran dalam format digital kini tersedia dalam berbagai versi. Meski demikian dalam beberapa penggunaan masih ada yang terbatas (Hizbullah, Fazlurrahman, \& Fauziah, 2016).

Digitalisasi merupakan salah satu dampak dari perkembangan teknologi. Adanya digitalisasi ini, media-media yang berbentuk hardcopy pun berubah wahana. Proses digitalisasi kini banyak dilakukan seperti pada majalah, surat kabar, buku, skripsi, jurnal, tesis, disertasi, dan lain sebagainya (Sukma, Nugroho, \& Zuryani, 2019). Al-Quran termasuk yang mengalami proses digitalisasi di era saat ini. Ada banyak jenis aplikasi alQuran digital yang dapat diunduh melalui berbagai website.

Aplikasi al-Quran (tafsir \& per kata) karya Greentech Apps Foundation dan al-Quran Muslim Media merupakan sample aplikasi alQuran yang banyak diminati oleh para pengguna android. Bahkan kedua aplikasi tersebut terbukti sama-sama telah menembus angka 100 ribu lebih pengguna yang mengunduh. Kedua aplikasi sama-sama memiliki fitur yang memudahkan penggunanya untuk bisa membaca maupun memahami al-Quran. Kedua aplikasi ini tentu memiliki keunggulan masing-masing sehingga membuat pengguna banyak mengunduhnya. Selain itu, kedua aplikasi tersebut juga punya kekurangan masing-masing. Tidak banyak yang mengetahui informasi mengenai latar belakang pembentukan serta perbedaan terkait fitur-fitur daripada aplikasi alQuran (tafsir \& per kata) karya Greentech Apps Foundation dan al-Quran Muslim Media. Serta tidak banyak yang mengetahui kelebihan dan kekurangan pada masing-masing aplikasi. Oleh karenanya hal demikian 
Jurnal Riset Agama, Volume 1, Nomor 3 (Desember 2021): 132-156

Ahmad Yani, Hepni Putra, Andika, Muria Khusnun Nisa, Eka Mulyo

Yunus/Studi Perbandingan Fitur-Fitur Aplikasi Al-Quran Digital Karya

Greentech Apps Foundation dan Aplikasi Al-Quran Muslim Media untuk

Mengetahui Perbedaan Kedua Fitur aplikasi

perlu untuk diteliti. Adapun metode penelitian yang akan digunakan untuk mengetahui permasalahan tersebut yakni metode kualitatif dengan pendekatan deskriptif. Dengan demikian dapat diketahui bahwa tujuan daripada penelitian ini antara lain untuk mengetahui latar belakang pembentukan aplikasi al-Quran (tafsir \& per kata) karya Greentech Apps Foundation dan al-Quran Muslim Media, untuk mengetahui fitur-fitur aplikasi al-Quran (tafsir \& per kata) karya Greentech Apps Foundation dan al-Quran Muslim Media, untuk mengetahui kelebihan dan kekurangan kedua aplikasi tersebut, serta untuk mengetahui perbandingan fitur-fitur aplikasi al-Quran (tafsir \& per kata) karya Greentech Apps Foundation dan al-Quran Muslim Media. Penelitian ini diharapkan dapat bermanfaat untuk para pembaca sebagai wawasan terkait perbandingan antara aplikasi al-Quran (tafsir \& per kata) karya Greentech Apps Foundation serta aplikasi al-Quran Muslim Media. Oleh karenanya peneliti bermaksud memberi judul penelitian ini dengan judul "Studi Perbandingan Fitur-fitur Aplikasi Al-Quran Digital Karya Greentech Apps Foundation dan Aplikasi Al-Quran Muslim Media Untuk Mengetahui Perbedaan Kedua Fitur Aplikasi."

Permasalahan utama penelitian ini adalah terdapat perbandingan fitur-fitur aplikasi al-Quran (tafsir \& per kata) karya Greentech Apps Foundation dan aplikasi al-Quran Muslim Media. Rumusan masalah penelitian ini ialah bagaimana perbandingan fitur-fitur aplikasi al-Quran (tafsir \& per kata) karya Greentech Apps Foundation dan aplikasi alQuran Muslim Media. Penelitian ini bertujuan membahas perbandingan fitur-fitur aplikasi al-Quran (tafsir \& per kata) karya Greentech Apps Foundation dan aplikasi al-Quran Muslim Media. Hasil penelitian ini diharapkan memberikan implikasi manfaat, baik secara teoritis maupun praktis. Secara teoritis, penelitian ini diharapkan dapat memberi wawasan terkait perbandingan fitur-fitur aplikasi al-Quran (tafsir \& per kata) karya Greentech Apps Foundation dan aplikasi al-Quran Muslim Media. Secara praktis, penelitian ini diharapkan menjadi rujukan dalam pembuatan aplikasi al-Quran digital dengan melihat pada perbandingan fitur-fitur aplikasi al-Quran (tafsir \& per kata) karya Greentech Apps Foundation dan aplikasi al-Quran Muslim Media kemudian mengambil kelebihan pada tiap-tiap aplikasi untuk dijadikan rujukan dalam pembuatan suatu aplikasi yang kemudian menghimpun kelebihan daripada kedua aplikasi al-Quran digital tersebut. 
Jurnal Riset Agama, Volume 1, Nomor 3 (Desember 2021): 132-156

Ahmad Yani, Hepni Putra, Andika, Muria Khusnun Nisa, Eka Mulyo Yunus/Studi Perbandingan Fitur-Fitur Aplikasi Al-Quran Digital Karya Greentech Apps Foundation dan Aplikasi Al-Quran Muslim Media untuk Mengetahui Perbedaan Kedua Fitur aplikasi

Bagan 1. Kerangka Berpikir

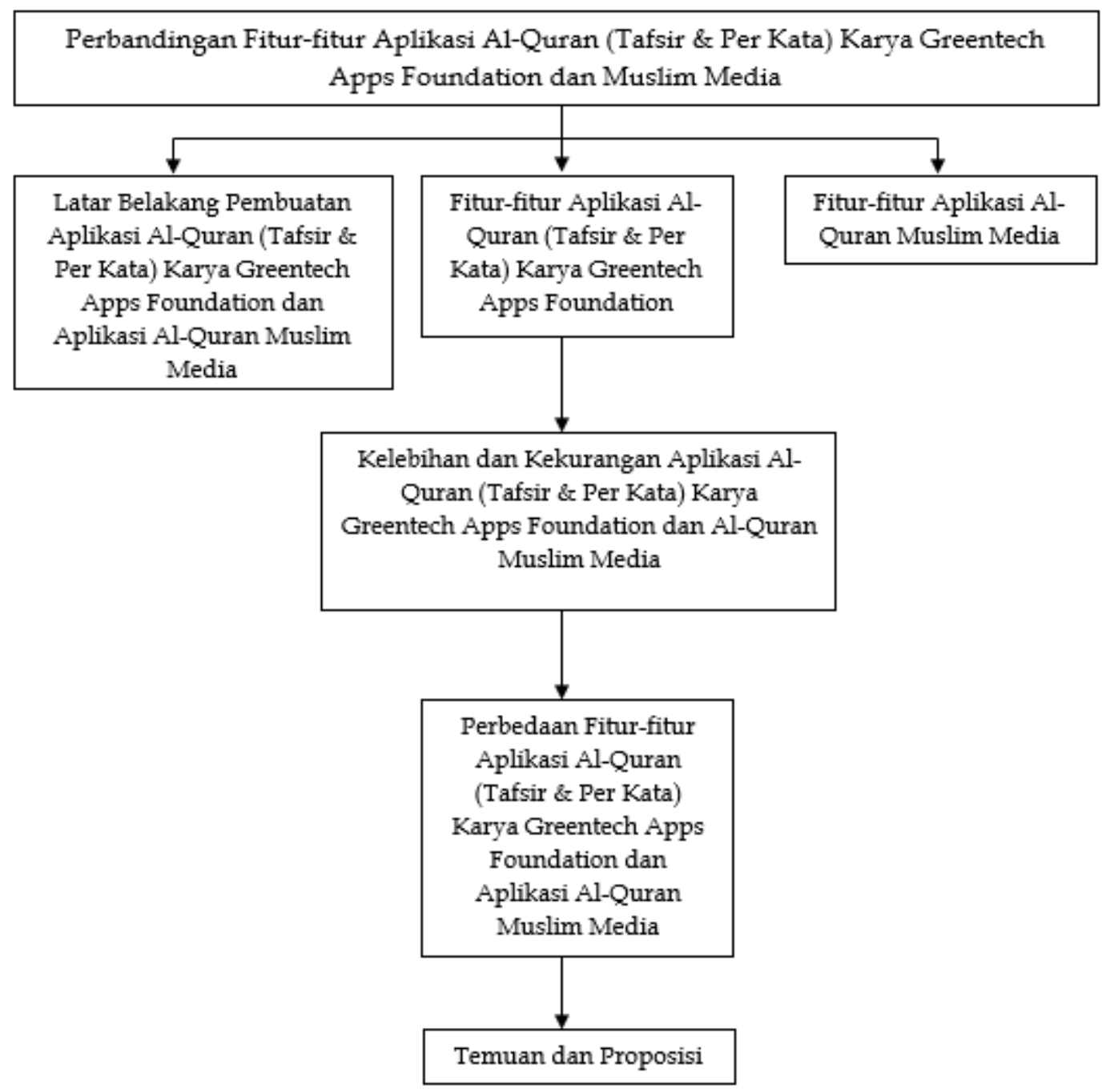

Sebagai langkah awal penelitian, kerangka berpikir sangat penting untuk dilakukan agar mengetahui bagaimana pertautan antara variabel yang hendak diteliti. Penelitian ini termasuk ke dalam jenis desain penelitian study cross sectional di mana dalam hal ini penelitian ini bertujuan untuk mengamati perbandingan fitur-fitur aplikasi al-Quran (tafsir \& per kata) karya Greentech Apps Foundation dan aplikasi alQuran Muslim Media. Study cross sectional yakni sebuah penelitian yang bertujuan untuk mengkaji dinamika keterkaitan antara faktor-faktor resiko dengan efek, melalui pendekatan observasi atau pengumpulan data sekaligus dalam suatu saat (poin time approach) (Siyoto \& Sodik, 2015). Tahap pertama yakni mengidentifikasi variabel-variabel yang akan diteliti serta kedudukan tiap variabel, dalam penelitian ini variabel independennya yakni latar belakang pembuatan aplikasi al-Quran (tafsir 
Jurnal Riset Agama, Volume 1, Nomor 3 (Desember 2021): 132-156

Ahmad Yani, Hepni Putra, Andika, Muria Khusnun Nisa, Eka Mulyo

Yunus/Studi Perbandingan Fitur-Fitur Aplikasi Al-Quran Digital Karya

Greentech Apps Foundation dan Aplikasi Al-Quran Muslim Media untuk

Mengetahui Perbedaan Kedua Fitur aplikasi

\& per kata) karya Greentech Apps Foundation dan al-Quran Muslim Media, fitur aplikasi al-Quran (tafsir per kata) karya Greentech Apps Foundation serta fitur aplikasi al-Quran Muslim Media. Kemudian variabel dependen dalam penelitian ini yakni perbedaan fitur-fitur aplikasi al-Quran (tafsir \& per kata) karya Greentech Apps Foundation dan aplikasi al-Quran Muslim Media. Kemudian dilanjut ketahap kedua yakni menetapkan subjek penelitian dan sampelnya. Subjek dalam penelitian ini yakni aplikasi al-Quran digital, namun dibatasi sampelnya yang terdiri dari aplikasi al-Quran (tafsir \& per kata) karya Greentech Apps Foundation dan aplikasi al-Quran Muslim Media. Setelah itu dilanjutkan dengan tahap ketiga yakni melakukan pengumpulan data, observasi maupun pengukuran atas variabel dependen-independen. Setelah terkumpul data, observasi maupun pengukuran atas variabel dependen-independen akan didapatkan kelebihan dan kekurangan aplikasi al-Quran (tafsir \& per kata) karya Greentech Apps Foundation dan aplikasi al-Quran Muslim Media. Baru kemudian pada tahap keempat atau yang terakhir yakni mengolah dan menganalisis data dengan cara membandingkan sehingga kemudian dapat dideskripsikan perbedaan fitur-fitur aplikasi al-Quran (tafsir \& per kata) karya Greentech Apps Foundation dan aplikasi al-Quran Muslim Media.

Penelitian terdahulu telah dilakukan oleh kalangan ahli. Antara lain Hidayat, S. (2016), “Al-Quran Digital (Ragam, Permasalahan dan Masa Depan)," Mukaddimah: Jurnal Studi Islam. Penelitian ini membahas mengenai al-Quran digital baik itu dari segi ragam, permasalahan dan masa depannya. Penelitian ini menggunakan pendekatan kualitatif dengan metode deskriptif-analitis. Hasil penelitian dan pembahasan menunjukkan bahwa al-Quran digital secara umum terbagi menjadi tiga ragam bentuk, al-Quran digital juga memiliki beberapa permasalahan yang dapat diatasi dengan beberapa cara, serta masa depan al-Quran digital seiring berkembangnya teknologi informasi dan komputer akan terus berkembang. Kesimpulan penelitian ini yakni al-Quran digital memiliki tiga ragam bentuk yakni bentuk software seperti holy quran, zekr, al-Quran, dan lainnya, permasalahan al-Quran digital yakni tidak dicantumkan sumber rujukan teks al-Quran secara jelas, tidak lengkap tanda baca terutama syakal, berkemungkinan salah input data, peluang adanya penyimpangan dari segi isi khususnya dari luar, masa depan alQuran digital kedepannya akan kian berkembang bahkan ke arah fungsi yang memiliki panca indra, baik itu pendengaran, peraba, perasa, penglihatan, hingga penciuman (Hidayat, 2016). (Adinda Putri Sukma et al., 2019), "Digitalisasi Al-Quran: Meninjau Batasan Antara yang Sakral dan yang Profan pada Aplikasi "Muslim Pro"," Sorot: Jurnal Ilmiah Sosiologi. Artikel ini berisi analisis dan penjelasan terkait batasan antara 
Jurnal Riset Agama, Volume 1, Nomor 3 (Desember 2021): 132-156

Ahmad Yani, Hepni Putra, Andika, Muria Khusnun Nisa, Eka Mulyo

Yunus/Studi Perbandingan Fitur-Fitur Aplikasi Al-Quran Digital Karya

Greentech Apps Foundation dan Aplikasi Al-Quran Muslim Media untuk

Mengetahui Perbedaan Kedua Fitur aplikasi

yang sakral dan yang profan dalam al-Quran aplikasi khususnya Muslim Pro. Pendekatan yang digunakan dalam penelitian ini adalah kualitatif dengan tipe eksplanatori deskriptif dan dianalisis menggunakan teori sakral dan profan Emile Pemikiran Durkheim dan Walter Benjamin tentang reproduksi mekanis. Melalui penelitian tersebut diketahui bahwa terdapat perbedaan perlakuan antara al-Quran dalam bentuk mushaf atau lembaran dengan bentuk digital al-Quran di aplikasi Muslim Pro telah membuat al-Quran digital kehilangan kesakralannya. Penelitian ini menyimpulkan bahwa al-Quran digital dalam aplikasi Muslim Pro dimensi sakralnya telah mengalami kepudaran akibat dimensi profan yang mendominasi sehingga al-Quran berbentuk mushaf yang awalnya selalu dilingkupi oleh berbagai ritual dan etika, setelah mengalami pereproduksian dalam bentuk digital, al-Quran terbebas dari hambatanhambatan dan berbagai tradisi yang melingkupinya seperti berbagai ritual dan etika sehingga menjadikannya kehilangan aura dan daya magisnya (A. P Sukma \& Dkk, 2019). Muzakky, A.H. (2020), "Al-Quran Di Era Gadget: Studi Deskriptif Aplikasi Quran Kemenag," Jurnal Studi Al-Quran: Membangun Tradisi Berpikir Qurani. Metode yang digunakan dalam artikel ini adalah deskriptif-analitis. Artikel ini berisi kajian dan eksplorasi terhadap aplikasi al-Quran Kemenag mulai latar belakang pengembangannya, fitur-fiturnya, pola penyajian al-Quran sampai kelebihan dan kekurangannya. Kesimpulan penelitian ini yakni aplikasi al-Quran Kemenag ini hadir memberikan manfaat yang signifikan kepada masyarakat di Indonesia, aplikasi al-Quran Kemenag RI ini dilengkapi dengan berbagai macam fitur serta asbab al-nuzul dari masing-masing ayat, adapun kekurangan pada aplikasi ini yakni pada bagian qiraat yang lebih menekankan akan muratal bukan dari segi tajwid maupun qiraatnya (Muzakky, 2020).

Penelitian terdahulu telah menyinggung digitalisasi al-Quran tetapi terkait dengan ragam, permasalahan dan masa depan al-Quran digital (Hidayat, 2016). Juga telah ditemukan berbagai pemaparan berkenaan dengan batasan antara yang sakral dan yang profan dalam al-Quran aplikasi khususnya Muslim Pro (A. P Sukma \& Dkk, 2019). Selain itu juga, telah didapatkan penelitian terkait kajian dan eksplorasi terhadap aplikasi al-Quran Kemenag mulai latar belakang pengembangannya, fiturfiturnya, pola penyajian al-Quran sampai kelebihan dan kekurangannya (Muzakky, 2020). Perbedaan penelitian ini dengan beberapa penelitian terdahulu yakni dalam penelitian ini dibahas mengenai studi perbandingan fitur-fitur aplikasi al-Quran (tafsir \& per kata) karya Greentech Apps Foundation dan aplikasi al-Quran Muslim Media dengan metode kualitatif-deskriptif. 
Jurnal Riset Agama, Volume 1, Nomor 3 (Desember 2021): 132-156

Ahmad Yani, Hepni Putra, Andika, Muria Khusnun Nisa, Eka Mulyo

Yunus/Studi Perbandingan Fitur-Fitur Aplikasi Al-Quran Digital Karya

Greentech Apps Foundation dan Aplikasi Al-Quran Muslim Media untuk

Mengetahui Perbedaan Kedua Fitur aplikasi

Dalam suatu penelitian, tinjauan pustaka sangat diperlukan guna menjadi landasan teoritis. Digitalisasi merupakan suatu terminologi yang diaplikasikan guna menerangkan terkait suatu proses peralihan dari media cetak, audio, video menjadi bentuk digital. Adanya digitalisasi ini bertujuan untuk menciptakan suatu arsip atau dokumen dalam bentuk digital. Sejarah merekam bahwa digitalisasi kian berkembang seiring berkembangnya teknologi. Bahkan al-Quran yang mulanya eksklusif serta mahal, kini dengan mudah didapatkan dan menjadi sesuatu yang populer. Al-Quran yang awalnya hanya ditulis dalam bentuk mushaf, kini dengan mudah didapatkan melalui bentuk digital (Mubarok \& Romdhoni, 2021). Digitalisasi al-Quran sangat penting untuk dilakukan dikarenakan pada masa kemajuan teknologi seperti saat ini, hal demikian sangat penting dalam rangka membangun pendidikan karakter agar generasi penerus bangsa dapat semakin nyaman dan sejahtera. Al-Quran dalam bentuk digital lebih mudah secara fisik untuk dibawa para pembacanya dalam masing-masing ponsel cerdas (smartphone) mereka (Hartono, 2021). Secara umum, al-Quran digital terbagi menjadi tiga bentuk, yakni dalam bentuk software, situs online, dan aplikasi ponsel (Hidayat, 2016). Adapun al-Quran digital dalam bentuk aplikasi ponsel saat ini mulai banyak bermunculan, mulai dari aplikasi Muslim Pro, Umma, Ayat, dan lain sebagainya. Termasuk juga aplikasi al-Quran (tafsir \& per kata) karya Greentech Apps Foundation dan al-Quran Muslim Media. Digitalisasi alQuran akan terus berkembang mengikuti perkembangan ilmu pengetahuan dan teknologi dan tentunya hal tersebut akan dapat memberi kemudahan pemanfaatan dalam kehidupan (Hidayat, 2016).

\section{Metodologi Penelitian}

Dalam metodologi penelitian mencakup beberapa komponen yakni metode dan pendekatan penelitian, tempat penelitian, instrumen penelitian, sampel sumber data penelitian, teknik pengumpulan data, teknik analisis data, dan rencana pengujian keabsahan data (Hardani, 2020). Metode dan pendekatan penelitian dalam tulisan ini yakni deskriptif-analitis. Dalam penelitian ini, peneliti tidak memerlukan tempat penelitian serta tidak memerlukan instrumen penelitian melainkan peneliti akan melakukan observasi secara langsung terhadap aplikasi alQuran digital yang hendak diteliti. Adapun populasi penelitian ini yakni al-Quran digital, sedangkan sampel sumber data penelitiannya yakni alQuran (tafsir \& per kata) karya Greentech Apps Foundation dan al-Quran Muslim Media. Teknik pengumpulan data yang digunakan dalam penelitian ini adalah observasi serta dokumentasi. Adapun teknik analisis data yang digunakan dalam penelitian ini adalah teknik analisis data kualitatif. Menganalisis data dalam sebuah penelitian kualitatif yakni manakala mengumpulkan data. Dengan demikian data tersebut bisa 
Jurnal Riset Agama, Volume 1, Nomor 3 (Desember 2021): 132-156

Ahmad Yani, Hepni Putra, Andika, Muria Khusnun Nisa, Eka Mulyo

Yunus/Studi Perbandingan Fitur-Fitur Aplikasi Al-Quran Digital Karya

Greentech Apps Foundation dan Aplikasi Al-Quran Muslim Media untuk

Mengetahui Perbedaan Kedua Fitur aplikasi

direduksi, reduksi data yakni upaya menyimpulkan data, lalu memilah data tersebut menjadi satuan konsep tertentu. Hasil reduksi data tersebut diolah sedemikian rupa sehingga terlihat sosoknya secara lebih utuh. Sosok tersebut boleh berbentuk sinopsis, matriks, maupun sketsa serta bentuk lainnya; hal ini benar-benar diperlukan guna memudahkan pemaparan serta penegasan kesimpulan. Proses tersebut tidak langsung sekali jadi, namun harus melalui pola interaksi bolak balik. Dengan demikian data dapat disajikan serta dapat disimpulkan dan diverifikasi keabsahannya melalui pola interaksi tersebut (Rijali, 2018).

\section{Hasil dan Pembahasan}

\section{Latar Belakang Pembuatan Aplikasi Al-Quran (Tafsir \& Per Kata) Karya Greentech Apps Foundation dan Aplikasi Al-Quran Muslim Media}

Al-Quran merupakan landasan hukum yang dijadikan sebagai pedoman hidup umat muslim. Al-Quran berisikan firman-firman Allah SWT yang diturunkan kepada Nabi Muhammad dengan perantara ruh alamin (malaikat Jibril) untuk dibaca, dipahami dan diamalkan, sebagai kitab suci umat Islam (Zarkasyi \& Akbar, 2020). Saat ini perkembangan mushaf al-Quran telah merambah pada era mushaf digital. Mushaf digital banyak dikembangkan seiring dengan meningkatnya teknologi IT. Umumnya dikemas dalam bentuk audio-visual. Untuk jenis audio-visual biasanya dihiasi dekorasi atau iluminasi yang indah dan menarik untuk dilihat. Demikian juga jenis khat yang disalin dalam al-Quran digital tersebut (Lestari, 2016).

Berdasarkan sensus penduduk oleh Badan Pusat Statistik pada 2010, Indonesia merupakan negara dengan jumlah penduduk beragama Islam terbanyak di dunia yaitu 207,18 juta jiwa atau $87,18 \%$ dari jumlah penduduk Indonesia. Salah satu pedoman bagi umat Islam dalam menjalankan kehidupan adalah kitab al-Quran. Kebutuhan ketersediaan al-Quran berbanding lurus dengan banyaknya penduduk Islam di Indonesia, baik al-Quran dalam bentuk cetak maupun digital. Kini, dengan perkembangan teknologi informasi seseorang dapat mengakses alQuran melalui berbagai media digital seperti smartphone, tablet, dan laptop. Format al-Quran digital yang dapat diakses meliputi format portable data file (pdf), file teks, aplikasi, e-book, unicode dan lain-lain. Penggunaan al-Quran digital mengalami peningkatan sejak tahun 2007 (Liyanti \& Hakim, 2019: 41). Peningkatan penggunaan tersebut juga dapat dijumpai dalam aplikasi al-Quran (tafsir \& per kata) karya Greentech Apps Foundation. Aplikasi al-Quran (tafsir \& per kata) karya Greentech Apps Foundation sendiri tentu memiliki sejarah awal mulai dari tidak memiliki pengguna hingga kemudian digunakan oleh banyak negara. 
Jurnal Riset Agama, Volume 1, Nomor 3 (Desember 2021): 132-156

Ahmad Yani, Hepni Putra, Andika, Muria Khusnun Nisa, Eka Mulyo

Yunus/Studi Perbandingan Fitur-Fitur Aplikasi Al-Quran Digital Karya

Greentech Apps Foundation dan Aplikasi Al-Quran Muslim Media untuk

Mengetahui Perbedaan Kedua Fitur aplikasi

Awal mula dibuatnya aplikasi al-Quran (tafsir \& per kata) karya Greentech Apps Foundation ini dikarenakan banyak sekali muslim yang merasa cukup memahami al-Quran hanya dengan membaca terjemahannya saja. Hal ini sungguh sangat berbahaya, karena akan menimbulkan kesalahpahaman atas makna yang terkandung dalam alQuran. Dengan hadirnya berbagai literatur Arab yang sudah diterjemahkan ke dalam bahasa Indonesia, maka problem ini seketika terpecahkan. Bukan hanya dalam bentuk buku, akan tetapi sekarang tersedia begitu banyak software yang menyediakan akan kebutuhan ini.

Software bernama "Al-Quran (Tafsir \& Per Kata)" versi 1.8.1 hadir dengan fitur yang begitu lengkap dan menjamin kepuasan para penggunanya. Cara mendapatkannya pun begitu mudah, tinggal buka aplikasi Play Store di Android masing-masing, kemudian sentuh icon search di pojok kanan atas dan silahkan tulis "Al-Quran (Tafsir \& Per Kata)". Software ini dirilis pada tanggal 26 Agustus 2016 oleh Greentech Apps Foundation dan sudah mengalami banyak sekali perubahan. Sekarang sudah ter-upgrade ke versi 1.8.1. Pembaharuan terakhir tercatat pada tanggal 4 November 2020. Pendiri perusahaan Greentech tidak diketahui secara spesifik dari aplikasi ataupun dari website resminya yakni www.gtaf.org.

Developer aplikasi al-Quran (tafsir \& per kata) yakni Greentech Apps Foundation. Aplikasi ini dapat di-install pada smartphone android versi 4.0 ke atas. Adapun ukuran aplikasi ini yakni 16 megabyte. Aplikasi ini telah diunduh melalui sebanyak lebih dari 1.000.000 kali dengan rating 4.8/5 berdasarkan rating Google Play. Aplikasi al-Quran (tafsir \& per kata) karya Greentech Apps Foundation ini dapat diunduh secara gratis.

Banyak sekali fitur dan keunggulan yang terdapat di dalamnya, di antaranya adalah audio ayat per ayat dengan fungsi pengulangan, kitabkitab tafsir, kode tajwid berwarna, analisa kata per kata sekaligus terjemahannya, indeks al-Quran, penelitian catatan, penanda bacaan sesuai keinginan pengguna beserta penyelarasannya, fitur pencarian yang sangat handal, bermacam-macam tema dan font huruf, dan banyak lagi.

Tersedia juga berbagai produk-produk tafsir dari berbagai masa, akan tetapi, hanya ada tiga kitab tafsir yang berbahasa Indonesia, yaitu tafsir Jalalayn, tafsir Ibnu Katsir, dan tafsir Kemenag RI. Untuk menambahkan kitab-kitab tafsir tersebut ke layar utama software perlu untuk mengunduhnya terlebih dahulu. Tidak hanya itu, beberapa terjemahan dalam berbagai bahasa dapat dilihat secara bersamaan. Model terjemahannya adalah kata per-kata, ditambah dengan keterangan mengenai tata bahasa, akar kata, dan rincian bentuk kata. Dengan ini para pengguna bisa membedakan antara kata kerja, kata benda, dan huruf. 
Jurnal Riset Agama, Volume 1, Nomor 3 (Desember 2021): 132-156

Ahmad Yani, Hepni Putra, Andika, Muria Khusnun Nisa, Eka Mulyo

Yunus/Studi Perbandingan Fitur-Fitur Aplikasi Al-Quran Digital Karya

Greentech Apps Foundation dan Aplikasi Al-Quran Muslim Media untuk

Mengetahui Perbedaan Kedua Fitur aplikasi

Terdapat juga kode tajwid berwarna untuk memudahkan pengguna dalam mengidentifikasi.

Sejumlah audio para qari terkenal juga bisa didapatkan di dalam software ini. Di antaranya adalah Imam Abdurrahman As-Sudais, Imam Abd Al-Basit Mujawwad, Abu Bakr Ash-Shatiri, Imam Mishari Rasyid, Syaikh Saad Al-Ghamidi, Syaikh Muhammad Jebril, dan lain sebagaianya. Sajian ini dapat memudahkan para pengguna untuk menghafalkan alQuran atau men-tashih bacaan al-Quran. Ukuran font, baik font Arab maupun Indonesia dapat diatur sesuai kebutuhan. Dihadirkan juga beberapa tipe mushaf, mulai dari mushaf unicode text, classic madani mushaf, warsy, qaloon, shemerly, sampai naskh indopak.

Bagaimanapun juga, peneliti rasa software ini sangat praktis dan begitu memudahkan bagi para penggunanya dalam mempelajari pedoman hidupnya, yakni al-Quran. Dengan hadirnya software-software semacam ini diharapkan dapat memecahkan problematika yang terjadi saat ini. seorang muslim tidak semestinya menafsirkan al-Quran sendiri tanpa berpegang pada penafsiran para mufassir. Setiap muslim juga harus mulai memperbarui cara berpikirnya, jangan sampai merasa cukup hanya dengan membaca dan menghafalkannya saja. Ia harus mengamalkannya di kehidupan nyata. Itulah tujuan utama mengapa al-Quran diturunkan ke dunia ini. Ia adalah pedoman hidup, bukan hanya bahan bacaan dan hafalan belaka.

Buat khalayak yang mencari aplikasi al-Quran bahasa Indonesia terbaik yang penuh dengan fitur menarik, khalayak bisa coba aplikasi alQuran (tafsir \& per kata) karya Greentech Apps Foundation. Beberapa fitur menarik yang terdapat di aplikasi ini adalah tafsir, kode tajwid berwarna, terjemahan kata per kata, hingga memilih tema. Selain itu, buat pengguna yang suka menulis catatan agar tidak lupa, aplikasi ini juga memungkinkan pengguna untuk bisa menulis catatan pada setiap ayatnya. Tidak hanya fitur bacaan teks al-Quran saja. Melalui aplikasi ini, pengguna juga bisa mendengarkan lantunan ayat suci yang dibacakan oleh lebih dari 30 qari, dan aplikasi ini ada pilihan bahasa Indonesia.

Adapun latar belakang pembuatan aplikasi al-Quran Muslim Media yakni aplikasi al-Quran Muslim Media dibuat oleh salah satu developer android yang menamai dirinya dengan nama Muslim Media. Muslim Media adalah android developer yang telah aktif sejak tahun 2017. Setidaknya ada 8 aplikasi yang telah dikembangkan oleh Muslim Media berdasarkan portofolio terbaru dari Muslim Media. Adapun beberapa aplikasi penting yang telah dikembangkan dan dibuat oleh Muslim Media adalah aplikasi al-Quran per kata dan tafsir, aplikasi al-Quran dan tafsir, dan aplikasi tafsir Ibnu Katsir. Dalam penelitian ini aplikasi yang hendak diteliti oleh peneliti adalah aplikasi al-Quran per kata dan tafsir namun 
Jurnal Riset Agama, Volume 1, Nomor 3 (Desember 2021): 132-156

Ahmad Yani, Hepni Putra, Andika, Muria Khusnun Nisa, Eka Mulyo

Yunus/Studi Perbandingan Fitur-Fitur Aplikasi Al-Quran Digital Karya

Greentech Apps Foundation dan Aplikasi Al-Quran Muslim Media untuk

Mengetahui Perbedaan Kedua Fitur aplikasi

peneliti akan menyebutnya sebagai al-Quran Muslim Media agar mempermudah dalam membedakannya dengan aplikasi al-Quran (tafsir \& per kata) karya Greentech Apps Foundation.

Aplikasi al-Quran Muslim Media telah mencapai versi 3.0.7 di tahun 2021. Telah mengalami pembaharuan pada 24 Juni 2021 sejak penelitian ini dibuat. Aplikasi ini juga telah diunduh sebanyak 100.000+ download. Aplikasi ini pertama kali rilis pada tanggal 19 Februari 2017.

Developer Muslim Media memiliki website resmi tersendiri. Adapun website resmi dari Muslim Media adalah www.devmuslim.com. Pada website tersebut disebutkan terkait kebijakan privasi. Adapun kebijakan privasi yang ada dalam website tersebut sebagai keterangan untuk para pengguna aplikasi yang diciptakan oleh Muslim Media terkait data pribadi yang dikumpulkan oleh Muslim Media serta bagaimana Muslim Media mengumpulkannya.

Developer Muslim Media mengumpulkan alamat Gmail melalui aplikasi yang dibuatnya, termasuk aplikasi al-Quran tafsir dan per kata. Pengumpulan alamat Gmail tersebut bertujuan untuk menyimpan data di Cloud. Cloud membantu aplikasi agar dapat menyimpan data (seperti bookmark dan catatan). Dengan adanya Gmail dan Cloud akan membantu dalam mengidentifikasi kembali data pengguna aplikasi manakala melakukan restore atau import data.

Aplikasi al-Quran dan tafsir per kata karya Muslim Media juga menyimpan foto profil akun Gmail pengguna. Hal ini untuk ditampilkan pada dashboard aplikasi. Foto profil ini hanya disimpan pada perangkat perpengguna saja namun tidak akan dikirim ke Cloud bersamaan dengan data pengguna.

Aplikasi yang dibuat Muslim Media juga memerlukan informasi lokasi. Informasi lokasi tersebut untuk menjalankan fitur jadwal salat. Tanpa adanya informasi lokasi, aplikasi al-Quran dan tafsir per kata karya Muslim Media tidak dapat menjalankan fitur tersebut.

Aplikasi al-Quran Muslim Media juga memerlukan akses ke media penyimpanan. Sebelum pengguna aplikasi dapat mengunduh file audio dari server, aplikasi ini akan meminta ijin kepada pengguna untuk mengakses media penyimpanan di perangkat pengguna agar file audio tersebut dapat tersimpan manakala telah selesai terunduh dan dapat dibuka kembali untuk diputar melalui Media Player. Tanpa adanya ijin dari pengguna, maka file audio tidak akan bisa diputar di Media Player. Pada beberapa merek perangkat tertentu, mencoba memutar file audio tanpa memberikan ijin akses ke media penyimpanan akan menyebabkan force close (aplikasi ditutup dengan paksa).

\section{Fitur-Fitur Aplikasi Al-Quran (Tafsir \& Per Kata) Karya Greentech Apps Foundation}


Jurnal Riset Agama, Volume 1, Nomor 3 (Desember 2021): 132-156

Ahmad Yani, Hepni Putra, Andika, Muria Khusnun Nisa, Eka Mulyo Yunus/Studi Perbandingan Fitur-Fitur Aplikasi Al-Quran Digital Karya Greentech Apps Foundation dan Aplikasi Al-Quran Muslim Media untuk Mengetahui Perbedaan Kedua Fitur aplikasi

Aplikasi al-Quran (tafsir \& per kata) karya Greentech Apps Foundation memiliki banyak fitur yang bermanfaat bagi penggunanya. Pada bar navigasi bawah terdapat lima navigasi yakni baca, rencana, penanda-bacaan, catatan, dan ayat harian. Adapun pada header bagian kanan terdapat ikon search sedangkan pada header bagian kiri terdapat ikon menu pilihan tersembunyi. Pada aplikasi ini terdapat splash screen berupa logo daripada aplikasi al-Quran (tafsir \& per kata) karya Greentech Apps Foundation yang berwarna hijau.

Pada bar navigasi bawah bagian baca, terdapat beberapa menu akses yang memudahkan pengguna untuk membaca al-Quran. Pada bagian tersebut akan terlihat informasi surah al-Quran yang terakhir dibaca, akses cepat yang meliputi ayat al-kursi, as-Sajdah, dan al-Mulk, serta terdapat informasi pilihan surah yang hendak dibaca mulai dari al-Fatihah hingga al-Nas. Pada bagian informasi pilihan surah tersebut juga dapat dipilih berdasarkan kategori surat, halaman, juz, maupun hizb. Pada bagian surat maka akan muncul susunan persurat al-Quran. Bagian halaman akan muncul susunan per halaman al-Quran. Pada bagian juz akan muncul susunan per-juz al-Quran. Sedangkan pada bagian hizb akan muncul per-hizb al-Quran.

Pada bar navigasi bawah bagian rencana, pengguna dapat menambahkan planner atau rencana membaca al-Quran. Hal ini sangat memudahkan pengguna untuk membuat jadwal pribadi dalam membaca al-Quran. Pengguna dapat menambahkan nama, target batasan baca alQuran mulai dari surat mana hingga surat mana yang hendak dibaca, jumlah hari, pemberitahuan, bahkan waktu pemberitahuan.

Pada bar navigasi bawah bagian penanda-bacaan, pengguna dapat melihat hasil tanda baca al-Quran baik itu berdasarkan terakhir dibaca maupun kategori penanda baca yang telah pengguna buat secara mandiri. Selain itu juga pengguna dapat melakukan pengambilan tanda baca melalui tombol pengambilan. Tak hanya terhenti sampai di situ, pengguna juga dapat mengambil file penanda-bacaan dengan cara klik pengiriman yang nantinya otomatis tersimpan ke dalam cadangan quran_bookmarks di dalam folder unduhan.

Pada bar navigasi bawah bagian catatan, pengguna dapat menyaring catatan yang telah tersimpan di dalam aplikasi al-Quran (tafsir \& per kata) karya Greentech Apps Foundation. Selain itu juga pengguna dapat memasukkan data ke dalam aplikasi melalui tombol pengambilan dan mengeluarkan data catatan melalui tombol pengiriman. Pengguna juga dapat melakukan penyaringan data catatan melalui form yang bertuliskan ketuk untuk menyaring.

Pada bar navigasi bawah bagian ayat harian, pengguna akan menerima ayat harian yang dipilih oleh aplikasi al-Quran (tafsir \& per 
Jurnal Riset Agama, Volume 1, Nomor 3 (Desember 2021): 132-156

Ahmad Yani, Hepni Putra, Andika, Muria Khusnun Nisa, Eka Mulyo

Yunus/Studi Perbandingan Fitur-Fitur Aplikasi Al-Quran Digital Karya

Greentech Apps Foundation dan Aplikasi Al-Quran Muslim Media untuk

Mengetahui Perbedaan Kedua Fitur aplikasi

kata) karya Greentech Apps Foundation secara otomatis. Pengguna juga dapat klik tombol baca untuk membaca ayat harian tersebut lebih lanjut. Selain itu juga, pengguna dapat klik teks guna menyalin teks terjemahan ayat harian yang tersedia.

Pada header bagian kanan yang terdapat ikon search memiliki fungsi untuk mencari kata, ayat, terjemahan maupun tafsiran di dalam aplikasi al-Quran (tafsir \& per kata) karya Greentech Apps Foundation. Pengguna hanya perlu menuliskan hal yang hendak dicari pada kolom pencarian, kemudian pada bagian "pencarian pada" bisa diklik kemudian dipilih hendak mencari hal yang perlu dicari tersebut pada tafsiran yang mana, baik itu tafsir Kemenag RI, tafsir Ibnu Katsir, dan lain sebagainya. Dengan demikian akan otomatis memunculkan hasil pencarian yang hendak dicari oleh pengguna. Selain itu juga terdapat contoh penggunaannya di bawah kolom pencarian serta terdapat history daripada pencarian pengguna.

Pada header bagian kiri yang terdapat ikon menu yang tersembunyi memiliki fungsi menyembunyikan fitur-fitur tambahan dalam aplikasi alQuran (tafsir \& per kata) karya Greentech Apps Foundation. Pada menu yang tersembunyi tersebut manakala diklik akan muncul fitur lompat ke ayat dengan demikian pengguna dapat otomatis mencari ayat berdasarkan surat, ayat maupun halaman. Selain itu, terdapat juga notifications yang berisi pemberitahuan dari pihak pengelola aplikasi alQuran (tafsir \& per kata) karya Greentech Apps Foundation. Pada menu yang tersembunyi tersebut juga terdapat fitur Indeks Quran, di mana pengguna dapat melihat fitur Indeks Quran mulai dari abjad A hingga Z, pada fitur ini juga dilengkapi dengan fitur kolom pencarian fitur Indeks Quran yang dapat mempercepat pengguna dalam memaksimalkan fitur Indeks Quran ini. Pada bagian menu yang tersembunyi ini juga terdapat fitur kamus, di mana pengguna dapat mencari akar kata bahasa Arab beserta jumlah penggunaan kosakata tersebut dan juga terjemahan daripada kosakata yang dicari tersebut mulai dari alif hingga ya. Pada bagian menu tersembunyi ini juga terdapat pengaturan, ayo ber-shadaqah jariyah, rate app!, bantu kami menerjemahkan, berbagi aplikasi, help $\mathcal{E}$ support serta beberapa ikon social media yang terdiri dari ikon website, ikon facebook, ikon instagram dan ikon twitter yang mengarah pada link Greentech Apps Foundation.

Pada bagian pengaturan, pengguna dapat mengatur lima hal utama dalam aplikasi al-Quran (tafsir \& per kata) karya Greentech Apps Foundation. Lima hal utama tersebut yakni general, penampilan, pemberitahuan, sistem data, dan miscellaneous. Pada bagian general, pengguna dapat mengatur bahasa, munculkan tulisan Arab, munculkan terjemahan, pilihan terjemahan, kata per kata, bahasa kata per kata, dan 
Jurnal Riset Agama, Volume 1, Nomor 3 (Desember 2021): 132-156

Ahmad Yani, Hepni Putra, Andika, Muria Khusnun Nisa, Eka Mulyo

Yunus/Studi Perbandingan Fitur-Fitur Aplikasi Al-Quran Digital Karya

Greentech Apps Foundation dan Aplikasi Al-Quran Muslim Media untuk

Mengetahui Perbedaan Kedua Fitur aplikasi

jenis mushaf. Pada bagian penampilan, pengguna dapat mengatur tema, ukuran tulisan Arab, jenis huruf Arab, ukuran tulisan terjemahan, dan tajwid. Pada bagian pemberitahuan, pengguna dapat mengatur pemberitahuan harian dan waktu pemberitahuan. Pada bagian sistem data, pengguna dapat mengatur daftar petunjuk data al-Quran atau lebih tepatnya lokasi penyimpanan data baik data murattal maupun data lainnya. Pada bagian miscellaneous, pengguna dapat melakukan mengatur dan mengunduh audio pembacaan al-Quran, ragam tampilan dari kanan, layar tetap menyala, fixed top-bottom and navigation, bersihkan riwayat pencarian, dan membaca aturan tajwid.

Pada tampilan aplikasi al-Quran (tafsir \& per kata) karya Greentech Apps Foundation di bagian pemaparan ayat suci al-Quran persuratnya dapat diatur menjadi tampilan full Arab maupun tampilan yang disertai dengan terjemahan, pemenggalan kata per kata maupun disertai dengan tafsirannya. Ketika pengguna telah masuk kepada tampilan surat alQurannya maka pengguna dapat mengatur tampilannya dengan cara klik tombol tersembunyi pada bagian kanan. Setelah itu, pengguna dapat mengatur tampilan baik itu memunculkan tulisan Arab, memunculkan tafsir, terjemahan, kata per kata maupun tajwid. Selain itu juga pengguna dapat memilih jenis huruf Arab, ukuran font Arab, ukuran font terjemahan, jenis penerjemahan dan tafsir, pilihan jenis terjemahan kata per kata, tombol contribute dan juga pengaturan. Manakala pengguna melakukan klik pada salah satu kata di dalam al-Quran (tafsir \& per kata) karya Greentech Apps Foundation, akan muncul terjemahan, kata baku, akar kata, bahkan muncul juga uraian daripada kata yang diklik tersebut secara rinci. Selain itu pengguna juga dapat mengetahui jumlah ayat, serta letak di mana diturunkannya surat tersebut. Itulah beberapa fitur-fitur aplikasi al-Quran (tafsir \& per kata) karya Greentech Apps Foundation.

\section{Fitur-Fitur Aplikasi Al-Quran Muslim Media}

Fitur-fitur aplikasi al-Quran Muslim Media memiliki banyak fungsi. Pada aplikasi al-Quran per kata dan tafsir karya Muslim Media ini terdapat splash screen awal yang berisikan logo aplikasi al-Quran Muslim Media yang berwarna ungu dengan latar belakang putih dan memuat tulisan al-Quran per kata \& tafsir v.3.0.8 (v.3.0.8 tergantung pada versi aplikasi yang digunakan pengguna) serta bertuliskan developed by Muslim Media. Pada bagian navigasi bawah terdapat empat pilihan tombol navigasi, yang pertama yakni tombol untuk memilih warna tema aplikasi yang terdiri dari empat belas warna, kedua yakni tombol untuk memilih mode terang dan gelap, ketiga yakni tombol pencarian terjemahan, latin dan teks Arab, kemudian tombol terakhir atau tombol keempat yakni tombol baca al-Quran. Pada bagian header akan terlihat lokasi pengguna aplikasi yang terdiri dari kecamatan dan provinsi daripada lokasi 
Jurnal Riset Agama, Volume 1, Nomor 3 (Desember 2021): 132-156

Ahmad Yani, Hepni Putra, Andika, Muria Khusnun Nisa, Eka Mulyo

Yunus/Studi Perbandingan Fitur-Fitur Aplikasi Al-Quran Digital Karya

Greentech Apps Foundation dan Aplikasi Al-Quran Muslim Media untuk

Mengetahui Perbedaan Kedua Fitur aplikasi

pengguna serta terdapat tayangan teks terjemahan hadis beserta nomor hadis dan juga tema hadis yang berjalan dari kanan ke kiri. Pada bagian tengah terdapat lima tombol lagi yakni tombol tools, hadis, salat, doa-doa, dan tafsir, serta logo bertuliskan al-Quran al-Karim yang dikelilingi oleh kelima tombol tersebut. Pada bagian kirinya terdapat tanggal hijriyah serta jadwal waktu salat.

Pada bagian tombol tools, pengguna dapat melakukan backup/restore data aplikasi al-Quran Muslim Media dengan cara login ke akun Gmail. Pengguna juga dapat menghapus iklan dengan cara klik hapus iklan dengan biaya sebesar Rp 20.000. Pengguna juga dapat memberikan rating aplikasi, membaca kebijakan privasi, serta melihat panduan singkat aplikasi.

Pada bagian tombol hadis, pengguna dapat melihat beberapa hadits pilihan baik itu dari kitab bulughul maram, riyadhush shalihin, fathul bari, maupun hadits arba'in. Pada setiap pilihan kitab tersebut terdapat topiktopik tersendiri yang manakala diklik maka akan muncul hadis terkait topik tersebut dan penjelasannya. Tidak hanya itu, juga terdapat faidah pada setiap hadis yang termuat di dalamnya.

Pada bagian tombol salat, pengguna dapat mengatur alarm untuk waktu salat. Pengguna juga dapat melihat waktu hijriyah berdasarkan lokasi pengguna aplikasi al-Quran Muslim Media. Waktu yang tersedia yakni syuruq, zuhur, asar, magrib, isya dan subuh.

Pada bagian tombol doa-doa, pengguna dapat melihat doa-doa alQuran baik dari para Nabi, orang saleh dan lainnya. Pada setiap doa terdapat keterangan doa yang ada serta lokasi surat dan ayat yang mengandung doa tersebut. Fitur ini membantu pengguna untuk mendapatkan doa yang langsung bersumber dari al-Quran.

Pada bagian tombol tafsir, pengguna dapat melihat tafsir al-Quran. Dalam aplikasi ini, tersedia tafsir Kemenag RI, tafsir ringkas Kemenag RI, tafsir al-Muyassar, dan tafsir Jalalayn. Keempat tafsir tersebut dipaparkan dalam bahasa Indonesia. Pada bagian ini juga terdapat quick access untuk melihat daftar surah mulai dari al-Fatihah hingga al-Nas. Pengguna juga dapat memanfaatkan fitur tambahan pada bagian internal tombol tafsir yakni fitur kontras, auto scroll, catatan dan penanda. Pada bagian ini, pengguna juga dapat klik tombol pengaturan pada bagian kanan atas untuk memilih perataan teks, sorotan teks, warna teks, tampilan teks Arab, keep screen on, halaman yang akan ditampilkan saat membuka tafsir, serta ukuran huruf.

Dalam aplikasi ini juga, pengguna dapat mencari nama surah secara cepat serta menyalin tafsiran yang ada di dalam aplikasi al-Quran Muslim Media. Selain itu juga, pengguna dapat mengunduh audio pembacaan murattal oleh beberapa qari'. Pengguna juga dapat memilih font Arab 
Jurnal Riset Agama, Volume 1, Nomor 3 (Desember 2021): 132-156

Ahmad Yani, Hepni Putra, Andika, Muria Khusnun Nisa, Eka Mulyo

Yunus/Studi Perbandingan Fitur-Fitur Aplikasi Al-Quran Digital Karya

Greentech Apps Foundation dan Aplikasi Al-Quran Muslim Media untuk

Mengetahui Perbedaan Kedua Fitur aplikasi

yang hendak dipakai, dalam aplikasi ini tersedia font lateef, scheherazade, dan kfgqpc uthmanic. Pengguna juga dapat memunculkan warna tajwid pada pengaturan. Selain itu, pengguna dapat memilih pilihan penulisan Arab, baik itu menggunakan Kemenag RI maupun Madinah. Pengguna dapat memunculkan tampilan latin ataupun menyembunyikannya. Pengguna juga dapat memunculkan dan menyembunyikan terjemahan serta memilih jenis terjemahan dan tafsiran. Demikian beberapa fitur aplikasi al-Quran Muslim Media.

\section{Kelebihan dan Kekurangan Aplikasi Al-Quran (Tafsir \& Per Kata) Karya Greentech Apps Foundation dan Al-Quran Muslim Media}

Dalam setiap perkara dari ciptaan Allah yang bersifat baru tentunya mempunyai kelebihan dan kekurangan. Bahkan dalam pembahasan ini peneliti dapat menemukan ada beberapa kelebihan atau keunggulan yang terdapat pada aplikasi al-Quran (tafsir dan per kata) karya Greentech Apps Foundation di antaranya adalah pertama, fitur aturan tajwidnya memiliki warna yang berbeda pada setiap hukum bacaan yang terdapat pada ayat-ayat al-Qurannya sehingga kita sebagai pembaca alQuran melalui aplikasi tersebut dapat mengetahui dan lebih memperhatikan ketika membaca baik itu dari segi bacaan jelas, dengung samar dan lain sebagainya. Selain itu juga terdapat murattal yang dapat dipelajari sebagai tuntunan dan bahan pelajaran yang baik dan bernilai estetis. Kedua, terdapat banyak sekali kita jumpai aplikasi al-Quran yang sudah diterbitkan dan banyak dipakai khalayak ramai di media android, namun tidak banyak dalam peluncuran aplikasi al-Quran tersebut yang diiringi dengan fitur terjemahan per kata sekaligus tafsir di dalamnya, beda halnya dengan aplikasi al-Quran (tafsir \& per kata) karya Greentech Apps Foundation ini yang telah memuat fitur terjemahan per kata sekaligus tafsir di dalamnya. Ketiga, adanya fitur kamus yang tersedia di dalam aplikasi al-Quran (tafsir dan per kata) karya Greentech Apps Foundation yang sangat memudahkan dalam pencarian kata yang diinginkan dengan fitur abjad ini sangat mudah diakses dan tidak dipungut biaya untuk diunduh pada Play Store dan App Store, sehingga masyarakat dapat dengan mudah untuk mengaksesnya. Kelima, sistem audio-visual dengan beberapa murattal diiringi oleh irama Imam ternama seperti Imam Abdurrahman As-Sudais, Abu Bakar Ash-Shatri, 'Abd Al-Basir Al-Mujawwad, dan banyak irama Imam lainnya dengan fungsi pengulangan, guna membantu dalam menghafal. Software yang dibuat oleh Greentech Apps Foundation ini telah diterjemahkan ke dalam berbagai bahasa. Menunjukkan bahwa software ini sudah sangat mendunia.

Di antara kelebihan atau keunggulan daripada aplikasi al-Quran (tafsir dan per kata) karya Greentech Apps Foundation mestinya juga 
Jurnal Riset Agama, Volume 1, Nomor 3 (Desember 2021): 132-156

Ahmad Yani, Hepni Putra, Andika, Muria Khusnun Nisa, Eka Mulyo

Yunus/Studi Perbandingan Fitur-Fitur Aplikasi Al-Quran Digital Karya

Greentech Apps Foundation dan Aplikasi Al-Quran Muslim Media untuk

Mengetahui Perbedaan Kedua Fitur aplikasi

terdapat kekurangan di dalamnya, di antaranya dari penilaian peneliti adalah pertama dalam segi tajwidnya al-Quran (tafsir dan per kata) karya Greentech Apps Foundation hanya menandai dari beberapa hukum tajwid saja yaitu hukum nun sukun dan tanwin dan tidak mengiringi hukum tajwid lainnya seperti mad, baik itu mad thabi'i, mad 'iwad dan lain sebagainya. Sehingga para pembaca paham kepada hukum tajwid yang ditandai saja. Hal ini kemudian menjadi pertimbangan agar kedepannya diberikan muatan ilmu qiraat, atau rekomendasi semangat belajar membaca al-Quran dengan fasih, baik dan benar. Selain itu kekurangan yang dapat peneliti ketahui dalam aplikasi ini, sudah lazim kiranya di antara berbagai aplikasi al-Quran yang peneliti ketahui di antaranya alQuran Indonesia, kemudian al-Quran tafsir Ibnu katsir dan lain sebagainya, terdapat fitur jadwal salat/adzan yang tersedia dalam alQuran tersebut. Tapi dalam aplikasi ini al-Quran (tafsir \& per kata) karya Greentech Apps Foundation tidak tersedia fitur tersebut. Maka perlu kiranya dibuat pertimbangan untuk update selanjutnya dapat memuat hal tersebut guna untuk memudahkan para pengguna agar tidak harus mencari jadwal salat/adzan di aplikasi lain. Serta tidak terdapat fitur arah kiblat sebagaimana aplikasi al-Quran digital yang lain. Beberapa tanda waqaf yang diganti atau tidak sesuai dengan tanda waqaf yang kita temukan pada mushaf-mushaf al-Quran pada umumnya. Kemudian kesalahan pada fitur pilihan terjemahan Indonesia-Tafsir Ibnu Katsir, di mana tafsir tersebut sebenarnya merupakan terjemahan daripada kitab Lubab al-Tafsir min Ibni Katsir bukan terjemah daripada kitab tafsir Ibnu Katsir yang sebenarnya yakni Tafsir al-Qur'an al-'Azhim. Kemudian juga terdapat kesalahan pada terjemah bahasa Indonesia, penamaan surah al-Lahab diganti dengan al-Massad, di mana penamaan tersebut kurang dikenal oleh orang-orang awam, dan lain sebagainya. Walaupun demikian, pihak developer tidak tinggal diam. Melihat tanggapan atas komentar yang disampaikan, pihak developer terus membenahi dan menyempurnakan software yang mereka buat.

Adapun kelebihan atau keunggulan dari aplikasi al-Quran Muslim Media juga ada beberapa sebagaimana aplikasi al-Quran (tafsir \& per kata) karya Greentech Apps Foundation. Pertama, terdapat fitur jadwal salat yang memudahkan pengguna untuk mengetahui waktu adzan. Kedua, terdapat fitur arah kiblat yang membantu pengguna untuk menentukan arah Kiblat sesuai dengan lokasi pengguna. Ketiga, terdapat fitur doa-doa al-Quran yang mempermudah pengguna untuk mencari tahu ayat-ayat yang mengandung doa di dalam al-Quran. Keempat, terdapat fitur search terjemahan yang mempermudah pengguna untuk mencari informasi seputar terjemahan, latin maupun teks Arab al-Quran. Kelima, terdapat fitur auto scroll yang juga terdapat pada aplikasi al- 
Jurnal Riset Agama, Volume 1, Nomor 3 (Desember 2021): 132-156

Ahmad Yani, Hepni Putra, Andika, Muria Khusnun Nisa, Eka Mulyo

Yunus/Studi Perbandingan Fitur-Fitur Aplikasi Al-Quran Digital Karya

Greentech Apps Foundation dan Aplikasi Al-Quran Muslim Media untuk

Mengetahui Perbedaan Kedua Fitur aplikasi

Quran (tafsir \& per kata) karya Greentech Apps Foundation, tentu ini akan mempermudah pengguna untuk men-scroll ayat al-Quran secara otomatis. Keenam, terdapat fitur murottal yang terdiri dari 14 qari alQuran yang bebas dipilih oleh pengguna untuk didengarkan. Ketujuh, terdapat fitur tajwid, selain itu juga terdapat keterangan tajwid sebagai informasi warna-warna yang ada sesuai dengan tajwidnya, namun pada aplikasi ini hanya ada yang berbahasa Indonesia, beda halnya al-Quran (tafsir \& per kata) karya Greentech Apps Foundation yang dapat diganti bahasanya menjadi bahasa-bahasa lain.

Aplikasi al-Quran Muslim Media, selain memiliki kelebihan dan keunggulan, aplikasi tersebut juga memiliki kekurangan. Pertama, pilihan tafsir hanya ada empat. Kedua, tidak terdapat fitur kamus al-Quran sehingga terjemahan perkatanya tidak disebutkan berapa kali penggunaannya pada kata tertentu di dalam al-Quran. Ketiga, hanya terdapat satu bahasa terjemahan al-Quran saja, yakni bahasa Indonesia. Keempat, keterangan warna tajwid hanya tersedia dalam bahasa Indonesia, tidak ke dalam bahasa lain.

\section{Perbedaan Fitur-fitur Aplikasi Al-Quran (Tafsir \& Per Kata) Karya Greentech Apps Foundation dan Al-Quran Muslim Media}

Digitalisasi merupakan salah satu dampak dari perkembangan teknologi, digitalisasi berarti proses mengubah bentuk media dari awalnya berbentuk kertas maupun lembaran menjadi bentuk digital. Proses perubahan ini merupakan upaya untuk memudahkan seseorang mengakses informasi. Terkhususnya yang terjadi pada digitalisasi alQuran. Sudah banyak sekali dilakukan oleh para ahli untuk menerbitkan al-Quran digital dengan varian yang menarik sehingga para pembaca tertarik dan semakin gemar dalam membaca al-Quran. Sama halnya yang telah banyak dipakai oleh khalayak ramai, yakni aplikasi smartphone alQuran (tafsir \& per kata) karya Greentech Apps Foundation dan aplikasi al-Quran Muslim Media. Kedua aplikasi tersebut menampilkan beberapa fitur yang memiliki perbedaan tersendiri. Berikut hasil analisis peneliti terkait beberapa perbedaan fitur-fitur yang ada di dalam kedua aplikasi tersebut.

\section{a. Fitur Tafsir}

Fitur tafsir dalam aplikasi al-Quran (tafsir \& per kata) karya Greentech Apps Foundation dan al-Quran Muslim Media memiliki perbedaan tersendiri. Dalam aplikasi al-Quran (tafsir \& per kata) karya Greentech Apps Foundation terdapat sangat banyak bahasa yang bisa dipilih para pembaca sesuai yang diinginkan. Hal ini sangat membantu pengguna aplikasi ini terlebih bagi yang kurang paham dalam bahasa Arab atau pun bahasa yang lainnya dikarenakan dalam tafsir ini terdapat 70 tafsir dengan beberapa bahasa penerjemah di berbagai negara, mulai 
Jurnal Riset Agama, Volume 1, Nomor 3 (Desember 2021): 132-156

Ahmad Yani, Hepni Putra, Andika, Muria Khusnun Nisa, Eka Mulyo

Yunus/Studi Perbandingan Fitur-Fitur Aplikasi Al-Quran Digital Karya

Greentech Apps Foundation dan Aplikasi Al-Quran Muslim Media untuk

Mengetahui Perbedaan Kedua Fitur aplikasi

dari tafsir al-Muyassar, tafsir al-Qurtubi, tafsir at-Thabari dan lain sebagainya, serta dari terjemah bahasa Indonesia, Inggris, Arab, Hindi, dan lain sebagainya. Sedangkan dalam fitur aplikasi al-Quran Muslim Media ini, sejauh peneliti amati, hanya menyediakan empat tafsir di antaranya tafsir Kemenag RI, tafsir ringkas Kemenag RI, tafsir alMuyassar, dan tafsir Jalalayn dan hanya terdiri dari satu bahasa penerjemah yaitu bahasa Indonesia. Walau demikian, aplikasi al-Quran Muslim Media ini tentu masih saja sangat bermanfaat bagi penggunanya, karena tafsir-tafsir tersebut tertera di dalam bentuk bahasa Indonesia.

\section{b. Fitur Terjemah Per Kata}

Dalam aplikasi al-Quran (tafsir \& per kata) karya Greentech Apps Foundation, pengguna dapat melakukan penelusuran per kata pada tiap ayatnya serta dapat mengetahui berapa kali penggunaan suatu kata tertentu di dalam al-Quran sekaligus mengetahui letak kata yang dicari. Sedangkan dalam aplikasi al-Quran Muslim Media juga terdapat fitur terjemah per kata pada tiap ayatnya, akan tetapi pengguna tidak dapat melakukan penelusuran lebih lanjut terkait kata yang hendak dicari. Selain itu juga pengguna tidak bisa mengetahui berapa kali kata yang dicari tersebut digunakan di dalam al-Quran melalui aplikasi al-Quran Muslim Media.

\section{c. Fitur Audio}

Sudah lazim sepertinya di berbagai aplikasi al-Quran versi android fitur yang di dalamnya memuat fitur audio dengan beberapa tujuan dan manfaat yang sangat besar, di antaranya adalah untuk memudahkan meniru irama nada membaca al-Quran oleh para Imam besar terkenal, kemudian untuk membantu para kalangan penghafal al-Quran dengan cukup mendengarkannya saja. Pada hal ini, juga terdapat pada aplikasi alQuran (tafsir \& per kata) karya Greentech Apps Foundation dan al-Quran tafsir dan per kata karya Muslim Media.

Adapun fitur audio pada aplikasi al-Quran (tafsir \& per kata) karya Greentech Apps Foundation, terdapat 29 qari' terkenal yang tentunya dengan irama yang sangat nyaman didengar dan harus mengunduhnya terlebih dahulu jika ingin mendengarkan murattal tersebut, serta lengkap 114 surah dalam al-Quran mulai dari surah al-Fatihah sampai pada al$\mathrm{Na}>\mathrm{s}$, di antaranya adalah: Yasser Ad-Dussary, Abd Al-Basit, Abd AlBasit, Abd Al-Basit Al-Mujawwad, Abd Al-Basit Al-Mujawwad, Abdullah Basfar, Abdurrahman Al-Shahat, Abdurrahman Al-Sudais, Abu Bakr AshShatri, Ahmad Naurina, Al-Hajjaj Al-Souasi, Aziz Alili, Bandar Baleela, Hani Rifai, Husary, Ibrahim Walk, Karam Al-Alami, Mahmoud Ali AlBana, Minshawi Murattal, Misyhari Al-Afasy, Misyhari/Walk, Mohammad At-Tablawi, Muhammad Jibril, Naseer Al-Katami, Saad Al- 
Jurnal Riset Agama, Volume 1, Nomor 3 (Desember 2021): 132-156

Ahmad Yani, Hepni Putra, Andika, Muria Khusnun Nisa, Eka Mulyo

Yunus/Studi Perbandingan Fitur-Fitur Aplikasi Al-Quran Digital Karya

Greentech Apps Foundation dan Aplikasi Al-Quran Muslim Media untuk

Mengetahui Perbedaan Kedua Fitur aplikasi

Ghamdi, Sahl Yasin, Sahl Budair, Shood Ah-Shuraym, dan Yaseer AdDussary.

Sedangkan dalam fitur aplikasi al-Quran Muslim Media ini juga terdapat murattal audio yang tidak jauh berbeda dengan aplikasi al-Quran (tafsir \& per kata) karya Greentech Apps Foundation, hanya saja dalam aplikasi ini hanya menyediakan 14 qari' terkenal dan harus mengunduh terlebih dahulu jika ingin mendengarkan murottal tersebut. Di antara $q a>r i$ ' dalam aplikasi ini adalah: Misyhary Rasyid Al-Afasy, Sa'ad AlGhamidi, Hani Ar-Rifai, Abdul Basit, Abdullah Basfars, Abdullah AlMathrud, Abdurrahman As-Sudais, Abu Bakar Asy-Syatiri, Ali Jaber, AlAl-Hufaidzi, Mahmud al-Husary, Mahir Al-Mauqily, Saud As-Syuraim, dan Yaseer Ad-Dussary.

\section{d. Fitur Tajwid}

Proses pembelajaran agama sedikit demi sedikit sudah menambah ke dalam penggunaan teknologi sebagai media penyampaian ilmu agama, sehingga paradigma mempelajari ilmu agama yang terkesan klasik dan sulit, saat ini menjadi lebih modern dan mudah. Hal ini dikarenakan hadirnya media yang dapat digunakan yaitu media teknologi berbasis android yang terdapat di antaranya pada aplikasi al-Quran (tafsir \& per kata) karya Greentech Apps Foundation yang sangat memudahkan para pengguna dalam memahami tajwid. Tampilan pada fitur tajwid ini sangatlah menarik bagi pembaca, dengan warna warni yang ditentukan oleh aplikasi ini gunanya untuk menandai dari beberapa hukum bacaan tajwid, mulai dari tanda waqaf seperti waqaf lazim, waqaf la washal waqaf washal dan lain sebagainya. Selain itu juga, disebutkan jumlah dari waqafnya yang terdapat dalam al-Quran. Demikian juga pada aplikasi alQuran Muslim Media ini, dalam fitur tampilan tajwidnya juga sangat memudahkan pembaca, dengan didesain warna warni di antara hukum tajwid mulai dari hukum nun sukun dan tanwin terdapat dalam al-Quran. Warna-warna tersebut sangat berguna untuk mempermudah para pembaca memahami tajwid. Berikut warna-warna yang berfungsi sebagai penanda pada hukum tajwid yang terdapat dalam kedua aplikasi alQuran tersebut: Pink (Idgham bighunnah); Hijau (Ikhfa'); Orange (Idzhar); Toska (Iqlab); dan Merah (Idgham bila ghunnah).

\section{e. Fitur Tampilan Background}

Pada aplikasi al-Quran Muslim Media terdapat background yang sangat unik dengan beberapa tampilan, ada seperti al-Quran smartphone biasanya yang hanya dengan background putih, kemudian ada juga fitur mode gelap untuk menyesuaikan pembaca di mana harus menggunakan fitur tersebut pada keadaan yang gelap tanpa cahaya, dan uniknya lagi dalam aplikasi ini, terdapat background (latar belakang) dengan varian warna yang menarik sehingga para pembaca bisa menyesuaikan suasana 
Jurnal Riset Agama, Volume 1, Nomor 3 (Desember 2021): 132-156

Ahmad Yani, Hepni Putra, Andika, Muria Khusnun Nisa, Eka Mulyo

Yunus/Studi Perbandingan Fitur-Fitur Aplikasi Al-Quran Digital Karya

Greentech Apps Foundation dan Aplikasi Al-Quran Muslim Media untuk

Mengetahui Perbedaan Kedua Fitur aplikasi

hati mereka masing masing, di antaranya adalah: Warna aksen \#1 Cokelat Tua; Warna aksen \#2 Cokelat Muda; Warna aksen \#3 Oren; Warna aksen \#4 Kuning; Warna aksen \#5 Hijau Army; Warna aksen \#6 Hijau Muda; Warna aksen \#7 Toska; Warna aksen \#8 Biru Laut; Warna aksen \#9 Biru; Warna aksen \#10 Ungu Tua; Warna aksen \#11 Ungu Muda; Warna aksen \#12 Pink Tua; Warna aksen \#13 Pink Muda; dan Warna aksen \#14 Merah.

Berbeda dengan al-Quran greentech dalam fitur background, dalam aplikasi tersebut hanya menyediakan satu background saja yaitu warna putih dengan kombinasi warna hijau di atas dan di bawah tampilan.

\section{f. Fitur Kamus}

Sebagaimana yang dikatakan oleh Hamid Shadiq Qatibi memandang bahwa kamus merupakan sinonim dari kata mu'jam, memiliki fungsifungsi tertentu yaitu di antaranya adalah, menemukan makna sebuah kata, menetapkan pelafalan dan pengucapan, menetapkan ejaan, menelusuri asal-usul sebuah kata membedakan antara kata yang tidak lazim dan tidak terpakai serta menjelaskan kata-kata yang murni dan serapan.

Tidak terlepas dari aplikasi al-Quran smartphone, tentunya tidak semua menyediakan fitur kamus di dalamnya, namun yang ini terdapat pada aplikasi al-Quran (tafsir \& per kata) karya Greentech Apps Foundation yang mempunyai fitur kamus guna untuk memudahkan para pembaca untuk mencari kata di dalam al-Quran dengan mudah dengan menggunakan abjad alif, $b a^{\prime}, \quad t a^{\prime}$ dan seterusnya, kemudian ingin mengetahui berapakan jumlah kata yang digunakan dalam al-Quran. sedangkan kajian perbandingan dalam dua aplikasi ini yaitu aplikasi alQuran (tafsir \& per kata) karya Greentech Apps Foundation dengan alQuran Muslim Media, al-Quran Muslim Media tidak menyediakan kamus di dalamnya sehingga ini menjadi kekurangan tersendiri pada aplikasi tersebut. Walau demikian, kedua aplikasi sangat memiliki banyak manfaat.

\section{g. Fitur Doa}

Fitur doa ini hanya terdapat pada aplikasi al-Quran Muslim Media saja, sedangan dalam aplikasi al-Quran (tafsir \& per kata) karya Greentech Apps Foundation tidak tersedia di dalamnya, dalam fitur ini terdapat tiga kumpulan doa-doa yang berbeda, di antaranya doa para Nabi, orang sholeh, dan lainnya. sedangkan doa para Nabi dalam fitur ini tersedia 23 doa, doa orang sholeh berjumlah 8 doa, dan doa lainnya berjumlah 14 doa.

\section{h. Fitur Jadwal Salat}

Sama halnya persamaan pada dua aplikasi ini, pada fitur jadwal salat ini hanya terdapat pada aplikasi al-Quran Muslim Media dan tidak terdapat pada aplikasi al-Quran (tafsir \& per kata) karya Greentech Apps 
Jurnal Riset Agama, Volume 1, Nomor 3 (Desember 2021): 132-156

Ahmad Yani, Hepni Putra, Andika, Muria Khusnun Nisa, Eka Mulyo

Yunus/Studi Perbandingan Fitur-Fitur Aplikasi Al-Quran Digital Karya

Greentech Apps Foundation dan Aplikasi Al-Quran Muslim Media untuk

Mengetahui Perbedaan Kedua Fitur aplikasi

Foundation. Dalam pengaturan jadwal terkait waktu salat yang ditampilkan pada waktu yang ditetapkan pada aplikasi al-Quran Muslim Media, masing-masing telah diberi tambahan waktu dua menit untuk ikhtiyati (pengaman) sebagaimana yang tertera di website Bimas Islam Kemenag RI. Sedangkan info jadwal salat untuk perhitungan waktu dan tanggal, aplikasi ini menggunakan library open source (kode sumber terbuka) sebagai berikut. Pertama, kalkulasi waktu salat: sumber http://praytimes.org; Parameter: Berdasarkan garis lintang dan garis bujur; Penetapan waktu ashar: Panjang bayangan benda melebihi panjang benda; Penetapan waktu isya: 10 menit sebelum masuk waktu subuh; Penetapan waktu subuh: 20 derajat kemiringan matahari; Sumber data pembanding: https://bimaislam.kemenag.go.id. Kedua, perhitungan kalender Hijriyah: Sumber https://github.com/jodaOrg/joda-time; Metode perhitungan: Ummul Qura.

\section{Kesimpulan}

Aplikasi al-Quran Greentech dan aplikasi al-Quran Muslim Media memiliki perbedaan dari berbagai fitur yang dapat dibandingkan satu sama lain. Perbandingan tersebut dapat dilihat dari segi fitur tafsir, terjemah per kata, audio, tajwid, tampilan background, kamus, doa, dan jadwal salat. Kedua aplikasi tersebut sama-sama telah banyak memberikan manfaat bagi para penggunanya. Hasil penelitian ini diharapkan memberikan implikasi manfaat, baik secara teoritis maupun praktis. Secara teoritis, penelitian ini diharapkan dapat memberi wawasan terkait perbandingan fitur-fitur aplikasi al-Quran (tafsir \& per kata) karya Greentech Apps Foundation dan aplikasi al-Quran Muslim Media. Secara praktis, penelitian ini diharapkan menjadi rujukan dalam pembuatan aplikasi al-Quran digital dengan melihat pada perbandingan fitur-fitur aplikasi al-Quran (tafsir \& per kata) karya Greentech Apps Foundation dan aplikasi al-Quran Muslim Media kemudian mengambil kelebihan pada tiap-tiap aplikasi untuk dijadikan rujukan dalam pembuatan suatu aplikasi yang kemudian menghimpun kelebihan daripada kedua aplikasi al-Quran digital tersebut. Penelitian ini memiliki keterbatasan karena baru penelitian berupa studi perbandingan fitur-fitur aplikasi al-Quran (tafsir \& per kata) karya Greentech Apps Foundation dan aplikasi al-Quran tafsir dan per kata karya Muslim Media sehingga masih dibutuhkan penelitian lebih lanjut terutama terkait dengan pengetahuan digitalisasi al-Quran. Penelitian ini merekomendasikan kepada para ahli programming dan developer aplikasi agar kedepannya dapat mengembangkan aplikasi alQuran digital dengan mengedepankan sisi kelebihan daripada kedua aplikasi tersebut atau bahkan menambahkan fitur yang lebih baik lagi agar menjadi sebuah aplikasi yang lebih unggul di masa mendatang. 
Jurnal Riset Agama, Volume 1, Nomor 3 (Desember 2021): 132-156

Ahmad Yani, Hepni Putra, Andika, Muria Khusnun Nisa, Eka Mulyo

Yunus/Studi Perbandingan Fitur-Fitur Aplikasi Al-Quran Digital Karya Greentech Apps Foundation dan Aplikasi Al-Quran Muslim Media untuk Mengetahui Perbedaan Kedua Fitur aplikasi

Tentu hal demikian akan sangat memberikan manfaat yang banyak untuk para umat beragama Islam khususnya para pengguna android. 
Jurnal Riset Agama, Volume 1, Nomor 3 (Desember 2021): 132-156

Ahmad Yani, Hepni Putra, Andika, Muria Khusnun Nisa, Eka Mulyo

Yunus/Studi Perbandingan Fitur-Fitur Aplikasi Al-Quran Digital Karya

Greentech Apps Foundation dan Aplikasi Al-Quran Muslim Media untuk

Mengetahui Perbedaan Kedua Fitur aplikasi

\section{Referensi}

Aksin, N. (2016). Pandangan Islam Terhadap Pemanfaatan Media Sosial. Jurnal Informatika UPGRIS, 2(2), 119-126.

Hardani. (2020). Metode Penelitian Kualitatif \& Kuantitatif. Yogyakarta: Penerbit Pusaka Ilmu.

Hartono. (2021). Rekonstruksi Penulisan Teks Ayat Al-Quran Modern. AlBayan: Jurnal Ilmu Al-Quran Dan Hadits, 4(1), 232-243.

Hidayat, S. (2016). Al-Quran Digital: Ragam, Permasalahan dan Masa Depan. Mukaddimah: Jurnal Studi Islam, 1(1), 1-40.

Hizbullah, N., Fazlurrahman, \& Fauziah, F. (2016). Penyusunan Model Korpus Al-Quran Digital. Jurnal Al-Azhar Indonesia Seri Humaniora, 3(3), 215-227.

Lestari, L. (2016). Mushaf Al-Quran Nusantara: Perpaduan Islam dan Budaya Lokal. Jurnal At-Tibyan, 1(1), 173-198.

Liyanti, \& Hakim, A. R. (2019). Perancangan Penerapan Tanda Tangan Digital Sebagai Pengembangan Sistem Pelayanan Pentashihan AlQuran Digital. Jurnal Sistemasi, 8(1), 41-54.

Mubarok, M. F., \& Romdhoni, M. F. (2021). Digitalisasi Al-Qur'an dan Tafsir Media Sosial di Indonesia. Jurnal Iman Dan Spiritualitas, 1(1), 110-114.

Muzakky, A. H. (2020). Al-Quran di Era Gadget: Studi Deskriptif Aplikasi Qur'an Kemenag. Jurnal Studi Al-Qur'an: Membangun Tradisi Berpikir Qur'ani, 16(1), 55-68.

Rijali, A. (2018). Analisis Data Kualitatif. Jurnal Alhadharah, 17(33), 81-95.

Siyoto, S., \& Sodik, M. A. (2015). Dasar Metodologi Penelitian. Yogyakarta: Literasi Media Publishing.

Sukma, Adinda Putri, Nugroho, W. B., \& Zuryani, N. (2019). Digitalisasi Al-Quran: Meninjau Batasan Antara yang Sakral dan yang Profan pada Aplikasi "Muslim Pro." Jurnal Ilmiah Sosiologi (SOROT), 1(1), $1-15$.

Sukma, A. P, \& Dkk. (2019). Digitalisasi Al-Quran: Meninjau Batasan Antara yang Sakral dan yang Profan pada Aplikasi Muslim Pro. Sorot: Jurnal Ilmiah Sosiologi, 1(1), 1-15.

Zarkasyi, \& Akbar, M. A. (2020). Sistem Pendeteksi Pola Isim Muannats Pada Citra Al-Qur'an dengan Menggunakan Metode Mountford. TTS 4.0: Jurnal Teknologi Terapan \& Sains, 1(3), 121-132. 